\title{
TEACHER IDENTITY AS A ROOT OF TEACHER SELVES: PROFESSIONAL
} IDENTITY VS PERSONAL IDENTITY

Submitted: 2020-12-07

\author{
Yohana Triana Ina Weran, Paulus Kuswandono \\ Sanata Dharma University, Indonesia \\ Yohana.weran@gmail.com,Kus@usd.ac.id
}

Accepted: 2021-05-01

\begin{abstract}
This paper sought to investigate the relationship/gap between personal and professional identity experienced by a group of elementary school teachers in Sintang, West Borneo. In gathering the data, the researchers used questionnaire and divided it into two parts: close-ended statements in a form of Likert Scale and open-ended questions which asked the opinion of the teachers related to their personal and professional identity. This study employed a qualitative research, using the snowball sampling. The researchers distributed the questionnaire in form of Likert scale and continued it with open-ended questions. The questionnaire was then followed up by individual interview. The questions were posited to identify teachers' beliefs of their professional and personal identity. The research results reveal that there are three gap points between personal and professional identity within teacher, namely adjusting myself to the school's environment, trying to be a good parent for students, and controlling myself in the school. Recommendations for further research studies are also provided at the end of this paper.
\end{abstract}

Keywords: Personal identity, professional identity, gap between personal and professional identity.

\section{INTRODUCTION}

Teacher identity is known as the main role that takes an important part in the life of a teacher. Teacher identity involves teachers' work, learn and development, mistakes, obstacles, challenges and reflection (Akkerman \& Meijer, 2011). The topic of teacher identity discusses not only the methods and approaches that a teacher must achieve, but also recognizes the relationship between emotions and identity, government regulations that can influence the ideology of teacher identity, and more. Identity is not singular but multiple that live in individual simultaneously. The position of identity itself can be varied for example as a 'teacher' (Barkhuizen, 2019). Being a teacher requires feeling, it promotes teachers' behavior toward their students and how they overcome the difficulty occurred by this identity. Barkhuizen (2019) also highlights that identity is constructed to claim the position of teacher at work (school) and social community. According to Yazan (2019) teacher identity impact the idea of 'how to be' and 'how to understand' teachers' work and place in society. The challenges face by the teacher can be occurred from those places and identity is the way how teacher behave to the difficulty. Yazan (2019) also adds that teacher identity provides the foundation for teachers' instructional meaning making and decision making. This situation can be seen when teachers learn to teach, interact with students and parents, reflect themselves as a teacher; what kind of teacher they are, what they value and prioritize in their professional practice. 
Teacher identity proposed a teacher's professional identity as the beliefs, values, and commitments held by an individual in their beliefs to become a teacher and become a certain type of teacher. The concept of teacher identity has been used in research studies to illustrate how teachers understand themselves as teachers. The teacher identity is the experience that is lived, personal and professional beliefs, and dispositions that have an impact on the person of a teacher. Then, how does the teacher identity affect the lives of someone and is there any different in terms of characteristic of someone when they become a teacher? Canrinus, Helms-Lorenz, Beijaard, Buitink, \& Hofman (2011) stated that the self develops through interaction with the environment, producing a sociological component of myself (the me) and a more personal component. Day, Kington, Stobart, \& Sammons (2006) also stated that in teacher education the research literature indicate that knowledge of self is the important element in the way the teacher constructs their nature of their work and the event of the experience that they get link the strong connection between personal lives and professional role. It means that professional identity can affect the character or one's personal identity.

Identity comes from within a person to distinguish them from others, and this can be interpreted that identity is describing the uniqueness of someone. Identity is divided into two, namely, personal and professional identity. According to Canrinus et al (2011) professional identity is about how a teacher responds to school rules or can also be described as action of how teacher see themselves based on their interpretations of ongoing interaction with their context. In the study, Canrinus et al., (2011) stated that there are three dimensions that work within a teacher namely (1) personal dimension which discussed the life of a teacher outside of school activities. (2) professional dimension which discussed the social and policy expectations of what a good teacher is and teachers own educational ideals and (3) situational dimension describes the work environment of a teacher. In this study, the researchers would like to study the two dimensions of personal identity and professional identity.

Teacher professional identity is crucial factor in understanding teacher's professional lives and career decision making (Hong, 2010). Research studies have identified that teacher professional identity is the main aspect in teacher's motivation, effectiveness and retention. According to Hong (2010), the 'self' is important in constructing the way teachers interact with their surroundings and make a judgement in a given context. In this study, professional action is doing professional identity, which means that the way teachers perceive themselves influence their choice of action. Moreover, understanding teacher's professional identity is vital for gaining insight into crucial aspects of teachers' professional lives, such as decision-making, motivation, job satisfaction, emotion, and commitment. Whereas, Day et al (2006) stated that personal identity is the central to the analysis of a teachers' work and lives and effectiveness in which structure 
(external influences) and agency (one's ability to seek the goals). While professional identity is influenced by how teachers feel about themselves and how they feel about their students. This means that professional identity helps them to position or situate themselves in relation to the students and make appropriate adjustment in their practice, their beliefs about and engagement to the students.

Based on the study from Barkhuizen (2019), identity is continually under construction and identity works in teachers throughout their life. Identity itself has degree of durability depend on how strong teachers deal with it. Yazan (2019) also mentions that in teachers' identity there are two elements namely personal and professional identity. These elements help teachers to be a 'meaning making and decision making' (what they value and prioritize, what kind of teachers they are, and how they behave to their social community). Derived from these core studies of identity, the researchers sought to investigate the relationship between personal identity and professional identity, whether or not professional identity can affect someone character or it does not have relation at all. Based on the topic, the following is the research question: (1) What are the gaps between personal identity and professional identity experienced by a group of school teachers in Sintang?

\section{METHOD}

The main objective of this study is to investigate the gap between the personal and professional identity of teachers by employing descriptive qualitative research using snowball sampling. The participants of this study were ten elementary school teachers in Sintang, West Borneo. Sintang is the largest regency area in West Kalimantan. Sintang regency is one of the regencies in Indonesia that has initiative to accomplish sustainable development goals (Salim, Hidayat, Wulandari, Pratama, \& Ichwani, 2019). The development not only in economy but also in education. This is also the reason why the researchers decided to study about teacher identity in Sintang. The participants were the teachers of one of the private school in Sintang.

Their opinions were used to understand the gap between personal and professional identity within them. Steps of data collection are described in the following details. The first step taken was preparing the questionnaire in a google form. The questionnaire was divided into two parts. The first one was the questionnaire of the Likert Scale and the second was teacher opinion related to the research question. After that, there were also interview via social media to examine the gap between personal and professional identity within teachers. Before conducting the interview, the researchers asked the participants for permission whether they were willing to be interviewed. After obtaining permission from the participants, the researchers started to interview the participants via video call. Fortunately, the interviews were conducted when the teachers were at 
school so that they could use the existing school internet connection and were not being disadvantaged financially as a result of online interview. The results of the questionnaire and the answers from the participants and interviews were used by the researchers to look deeper into the gap between the professional and personal identity of teachers. Coding procedure was used to classify the themes of the qualitative findings.

\section{FINDING AND DISCUSSION}

Based on the results there are ten participants who were willing to fill out the questionnaire and interview. There are three main points that picture their identity as a teacher and a person. In this study, teacher identity is the main discussion that is related to the two parts of teacher, namely professional identity and personal identity. Based on the questionnaire and the interview, the participants point out several details of teacher identity as follow:

\begin{tabular}{|c|c|c|c|}
\hline No & Participants & Statements \\
\hline 1. & Participant 1 & "I have a kind of emotion that I must not reveal in front of students, that is why I \\
try to control myself when I am in a class"
\end{tabular}

Based on the result, the researchers find some unique points that stand as a picture of teacher identity namely: adjusting myself to the school's environment, trying to be a parents for the

Weran, Kuswandono. Teacher Identity.... 
students, and controlling myself in the school. First is adjusting themselves to the school environment.

\section{a. Adjusting myself to the school's environment}

In the answers given by the teachers, many responded that they had to adjust to the workplace. One of the teachers explained that to arrange themselves between personal and professional must start with 'adaptation' or adjust to the environment around the school. Another teacher also added that it is actually not easy to adjust to the school environment because personal attitudes are fairly emotional and straightforward but when in the school they have to adjust with the situation. The situation faced by the teacher is also explained in Yin (2012) study in the context of teaching and schooling, emotional labor can be described as a process in which teachers try to inhibit, generate and manage their feelings and expressions of emotions according to the normative beliefs and expectations held about the teaching profession. At first, it was very difficult, but over time, the teacher was able to adjust well. According to Sachs (2016) Teacher identity is identified as a member of the community, just as the participants explained that even though at first they found it difficult to adapt, it was one of the ways to survive in the school community because they are part of the community. Day et al., (2006) also describes personal identity as a form of cognitive and emotional identities. The same explanation was expressed by one of the teachers that the reason why initially it was difficult to adapt was due to emotional identities in themselves, especially because of their own characteristics. That is why adaptation is crucial related to the gap between personal and professional identity. Teachers being a part of community is also discussed by Alberto \& Castañeda (2011) in their study of teacher identity construction. In the study, they identify identity as the 'self' or social roles that play in the community. Teachers play as a social role in the community (school) and their beliefs, motivation, and emotion provide the notions of the 'self' that sometimes become a complex dimension of the professional lives of the teacher. That is why adaptation is one way for the teacher to adjust themselves in the community and the workplace (Sharplin, Neill, \& Chapman, 2011). In this study they gave an important point, namely person-environment fit assumes that human beings requisite interact with the environment in order to survive. Therefore, the action is determined jointly by the characteristics of the person and the properties of an environment. This study also underlines that the cause of job satisfaction is not on the job itself or from the people, but lies in the relationship between the two. Sharplin et al. (2011) also defines that commencing employment requires both social and professional adjustment that produces feelings of anxiety, stress, inadequacy, and isolation. This also relates to the novice teacher who has to filter out bad experiences as a lesson for them to plan ahead. Some of the participants who were willing to be interviewed were considered as new teachers who were 
also still learning to adapt to their work environment, fellow teachers, and also students. In this study, the participants also point out the relationship between work and fellow teachers, one participant said that to be able to stay in this job requires patience. Patience is meant to refrain from being selfish and open themselves to cooperate between teachers and students. Therefore, work and humans are not a separated entity but are related to one another.

\section{b. Trying to be a good parent for students}

Some teachers who participated in this study were young teachers who had been teaching for 1 up to 4 years and teachers who were married and had been teaching about 5 up to 10 years. Young teachers or novice teachers pointed out that at school, they had to control their emotions and behavior because they knew that being an elementary school teacher, they had to reflect good values, such as authoritative and friendly to students, so that they give the term of becoming good parents for the students. Likewise, senior teachers responded that they were always trying to be a good parent for the students in school, putting aside personal emotions, and focusing on the situation/background of students in school. Situations like this turned out to be in conflict with the personal identities for some teachers as they had no choice but to follow the rules. Based on the study from Day et al (2006), they stated that professional identity is influenced by how teacher feel about themselves and how they feel about their students That make teachers have such a responsibility as a 'second' parents for their students even though it is contrast with their personal identity. According to (Epstein, Becker, Epstein, \& Becker, 1982) the amount time of teachers in the school is not much because they need to prepare project, workshop, supervise, teaching and etc. Of course, this work involves many parties, both young teachers and senior teachers, so that young participants who are "required" to become second parents for students must think of good ways to socialize or communicate with students. Therefore, the right way is to socialize with parents about the condition of each student and try to practice it during school hours. Pillet-shore (2015) explain that as embodiments of the family institution, parents must also interact with other institutions (e.g., schools). During these inter-institutional encounters, they inescapably present the roles of becoming parents, how they do the job of "being a parent". In the article, the relationship between parents and teachers is also discussed in order to create a good strategy in stimulating the improvement of students in school. This statement is also supported by a study from Thomas, Keogh, \& Hay (2014) which explains the role of the teacher as a parent in school and relations to students' success at school. The reason why the participants in this study tried to become parents to the students was that the family environment was actually the most important factor in the success of the students (Thomas et al., 2014). Therefore, participants also would like to create a "family" situation in the school environment with the intention that students can 
improve their development in school both in academic and non-academic terms. The concept of being a parent in the school is also discussed by Wentzel (2002) who explains that parental influence occurs to socialization models of development. It occurs because parents actively teach children about themselves and what they need to do in their social world. As a result, children adopt this behaviour and apply it at school, at school the teacher helps as "parents" in completing what the students have learned at home. Cooperation between teachers and parents is a form of strategy in optimizing student development so that they can achieve the set goals and values.

\section{c. Controlling myself in the school}

In this section, the researchers discuss the problem that occurs in the process of knowing personal and professional identity. Most of the teachers answer about controlling themselves in front of the students. One teacher explained that the class situation, the readiness of students in the class, and even the doctrine of parents about the teacher's personality made it a problem for teachers to control themselves. The problems faced by teachers are also related to parents. Wentzel (2002) shows that when the relationship between parents and students is established and supportive, students are more likely to adopt and internalize expectations and goals that are valued by parents and teachers than if their relationship is abusive and critical. Many also discussed the difficulty of understanding the character of students and some also added that when in the classroom the teacher was unable to fully recognize themselves because they had to play a role as a professional. The situation and character of students in the classroom become an important issue in the process of introducing personal and professional identity. According to Day et al (2006), professional identity helps teachers to position or situate themselves in relation to the students and make appropriate adjustment in their practice, their beliefs about and engagement to the students. A study conducted by Hsieh (2014) explain that the situation in the classroom shaped the character of the teacher in terms of teaching and he also added that learning from mistakes in the classroom is very beneficial for the teacher. However, unfortunately in the situation faced by participants, mistakes must be minimized because as elementary school teachers they want to show at least the 'perfect' attitude of a teacher to students. Mistakes are good as a lesson but it would be better if not to do it as often as possible, this is also caused by the high expectation of the students and parents so that teacher also controls every word and action taken. According to Perry \& Ball (2016) teaching and learning processes are irretrievably emotional in nature, an understanding of the role that emotions play in the context of teaching become an essential factor of teaching practice. Moreover, Zembylas (2003) explain that teacher-self and teacher identity is a component that hides within the teacher that also expounds the myth that the teacher describes as an expert. This is why professional identity describes as a policy expectation. Most cases of 
teachers leaving their profession were because they cannot stand what they have to do, there are some who think that the predetermined expectations are not in accordance with the personal principles held so they decide to leave the job.

\section{CONCLUSION}

This study discusses the gap between personal and professional identity within the teacher in Sintang, West Borneo. The researchers focus on the relationship between these two elements and would like to investigate the relationship between personal and professional identity. The research question of this study is as follows: "what are the gaps between personal identity and professional identity?"

The teachers who participated in this study are elementary school teachers in Sintang, West Borneo. The data obtained from questionnaires were collected through Google form completion, and the results of the interviews. The research results have demonstrated that there are three essential points mostly answered from participants with regards to the relationship between personal identity and professional identity (gap), namely (1) adjusting myself to the school's environment, (2) trying to be a parents for the students, (3) controlling myself in the school.

The finding explains that there is a gap between personal and professional identity but the gap is not a barrier for teachers to get to know more about their identities and some even experience that professional identity influences their personal identity and even changes their lifestyle to become better. It can be concluded that despite the gaps in the personal and professional identity within the teacher, over time the teachers realize that personal and professional identity have a bond with each other that forms their identity as teachers not only within the school, but also the community outside the school environment. Further studies can be carried out using the same framework, but can focus more on the teachers' tensions that can transform themselves to embrace relatively new teacher professional identity. 


\section{REFERENCES}

Akkerman, S. F., \& Meijer, P. C. (2011). A dialogical approach to conceptualizing teacher identity. Teaching and Teacher Education, 27(2), 308-319. https://doi.org/10.1016/j.tate.2010.08.013

Alberto, J., \& Castañeda, F. (2011). TEACHER IDENTITY CONSTRUCTION: exploring the nature of becoming a primary school language teacher. (November).

Barkhuizen, G. (2019). Teacher identity. The Routledge Handbook of English Language Teacher Education, 536-552. https://doi.org/10.4324/9781315659824-36

Canrinus, E. T., Helms-Lorenz, M., Beijaard, D., Buitink, J., \& Hofman, A. (2011). Profiling teachers' sense of professional identity. Educational Studies, 37(5), 593608. https://doi.org/10.1080/03055698.2010.539857

Day, C., Kington, A., Stobart, G., \& Sammons, P. (2006). The personal and professional selves of teachers: Stable and unstable identities. British Educational Research Journal, 32(4), 601-616. https://doi.org/10.1080/01411920600775316

Epstein, J. L., Becker, H. J., Epstein, J. L., \& Becker, H. J. (1982). Teachers ' reported practices of parent. 83(2), 103-113.

Hong, J. Y. (2010). Pre-service and beginning teachers' professional identity and its relation to dropping out of the profession. Teaching and Teacher Education, 26(8), 1530-1543. https://doi.org/10.1016/j.tate.2010.06.003

Hsieh, B. (2014). The Importance of Orientation : Implications of Professional Identity on Classroom Practice and for Professional Learning Betina Hsieh The Importance of Orientation : Implications of Professional Identity on Classroom Practice and for Professional Learnin. Teacher Education Departement, 1-23.

Perry, C., \& Ball, I. (2016). Dealing constructively with negatively evaluated emotional situations: The key to understanding the different reactions of teachers with high and low levels of emotional intelligen. (May). https://doi.org/10.1007/s11218-0079025-Z

Pillet-shore, D. (2015). Being a "good parent" in parent - teacher conferences. 65, 373-395. https://doi.org/10.1111/jcom.12146

Sachs, J. (2016). Teacher professional identity : competing discourses , competing outcomes. (May). https://doi.org/10.1080/02680930116819 
Salim, A., Hidayat, S., Wulandari, R., Pratama, C. D., \& Ichwani, S. N. (2019). A green scenario for sustainable landscape planning: The case study in Sintang Regency, West Kalimantan Province. IOP Conference Series: Earth and Environmental Science, 399(1). https://doi.org/10.1088/1755-1315/399/1/012080

Sharplin, E., Neill, M. O., \& Chapman, A. (2011). Coping strategies for adaptation to new teacher appointments : Intervention for retention. Teaching and Teacher Education, 27(1), 136-146. https://doi.org/10.1016/j.tate.2010.07.010

Thomas, S., Keogh, J., \& Hay, S. (2014). Discourses of the good parent in attributing school success. (2001).

Wentzel, K. R. (2002). Are Effective Teachers like Good Parents? Teaching Styles and Student Adjustment in Early Adolescence. Wiley on behalf of the Society for Research in Child Development Stable URL : http://www.jstor.com/stab. 73(1), $287-301$

Yazan, B. (2019). Toward identity-oriented teacher education: Critical autoethnographic narrative. TESOL Journal, 10(1), 1-15. https://doi.org/10.1002/tesj.388

Yin, H. (2012). Educational Psychology : An international journal of experimental adaptation and validation of the teacher emotional labour strategy scale in China. (October 2014), 37-41. https://doi.org/10.1080/01443410.2012.674488

Zembylas, M. (2003). Interrogating "Teacher identity": Emotion, resistance, and selfformation. 53(1), 39-53. 